\title{
PROPERTIES OF ALPHA-L-FUCOSIDASE FOR SERUM OF PATIENTS WITH HEPATOCELLULAR CANCER AND CYTOTOXICITY ON SOME CANCER CELL LINES
}

\author{
Z. M. A. A. HAMODAT \\ University of Mosul, College of Science, Chemistry Department, Mosul - Iraq; \\ e-mail: zahraahamodat@uomosul.edu.iq
}

Received: 07 July 2021; Accepted: 12 November 2021

\begin{abstract}
Alpha-L-fucosidase (FUCA) degrades many fucosylated glycans and has long been recognized as a tumor marker associated with the early detection of some cancers. This study aimed to purify and characterize alpha-L-fucosidase from the serum of patients with hepatocellular cancer and estimate its toxic effect against hepatocellular carcinoma HepG2, prostate cancer PC3 cell lines and the standard hepatocyte WRL68 cell line. SDS-Page Electrophoresis technique was used to determine the purity of the purified alpha-L fucosidase and estimate its molecular weight. Three purification steps were used for FUCA purification: precipitation with 65\% ammonium sulfate saturation, DEAE-cellulose ion exchange, Sephadex G-75 gel filtration. The procedure resulted in 54\% recovery of the enzyme with 27.5 -fold purification and $14 \mathrm{U} / \mathrm{mg}$ specific activity. It was demonstrated that FUCA purified from the serum of HCC patients showed a more toxic effect on HepG2 cells (IC $C_{50}$ of $\left.65.74 \mu \mathrm{g} / \mathrm{ml}\right)$ than on PC3 prostate cancer cells $\left(I C_{50}\right.$ of $\left.111.5 \mathrm{~g} / \mathrm{ml}\right)$ and less toxic effect against standard hepatocyte WRL-68cells (IC ${ }_{50}$ of $214.5 \mu \mathrm{g} / \mathrm{ml}$ ). We can conclude that the inhibitory effect of the purified FUCA on hepatocellular carcinoma is more than its effect on prostate cancer cells. Also, the purified FUCA may be used in studies on anticancer drug development in liver cancer.
\end{abstract}

Ke y wo rd s: alpha-L-fucosidase, hepatocellular cancer, HepG2 and PC3 cell lines, ion exchange chromatography, gel filtration.

$\mathrm{H}$ epatocyte cancer (HCC) is the fifth and most common cause of death and the third cause of death associated with cancer [1-3]. Despite the progress made in recent decades, liver cancer (HCC) is still the most common disease and cause of death globally and in both sexes. According to the Cancer Society report in the United States for the year 2013, it was found that liver cancer ranks fifth in the world and that the number of deaths is 14,890 , which is the ninth common disease in the world with approximately 6,780 deaths [4]. To improve survival, it requires early detection and detection of HCC [3]. Most cases of HCC are in patients with cirrhosis or chronic liver disease that cause the release of inflammatory factors [2]. Metamorphosis and penetrance of the metastasis are characterized by increased attachment to fucose.
Fucosylation of oligosaccharides on glycoproteins or glycolipids is one of the most common oligosaccharide modifications. Fucosylation is the process of attaching a fucose residue to $\mathrm{N}$-glycans, O-glycans, and glycolipids. O-Fucosylation is a form of fucosylation that isn't found anywhere else. A specific type of fucosylation is required for Notch signaling the legal framework. Fucosylation mechanisms are tricky. Fucosyltransferases come in a variety of forms. The GDP-fucose production route, as well as the GDP-fucose transporter, are both involved in the process. Fucosylation regulation Fucosylation levels are higher in a recent study. Inflammation and cancer are two examples of unhealthy conditions [5, 6].

The lysosomal enzyme $\alpha$-L-fucosidase (EC 3.2.1.51; FUCA) removes terminal L-fucose residues from the glycoconjugate oligosaccharide

(C) 2021 Hamodat Z.M.A.A. This is an open-access article distributed under the terms of the Creative Commons Attribution License, which permits unrestricted use, distribution, and reproduction in any medium, provided the original author and source are credited. 
chains [4, 7-13]. The lipid enzyme FUCA, commonly found in mammalian cells, has been associated with the degradation and disturbance of alpha fucose levels. Whereas, the disorder in the level of fucose is not only associated with an increase of deformation of fucoglycones containing fucose such as glycoproteins, glycolipids, and mucopolysaccharides present on the surface of the cell, only with an increase or change of viable cells but also associated with an increase or change of the viability of the cell. Fucose is associated with tumor formation, lymphomagenesis, and vascular attack; therefore, FUCA can play an essential role in cancer diagnosis [14-16]. Given the importance of FUCA, $\alpha$-L-fucosidase's effectiveness has been studied in many sources [1, 4, 17-24]. Alpha-L-fucosidase degrades many fucosylated glycans and has long been recognized as a tumor marker associated with early detection of HCC and colorectal cancer [8, 12, 13, 22, 25-27].

The characteristics of $\alpha$-L-fucosidase can be extracted, purified, and tested in HCC serum as a valuable early detection and illness progression indicator. On the other hand, $\alpha$-L-fucosidase activity has previously been reported as a useful marker for detecting illness in primary serum hepatocytes [11, 36-40]. The results of the FUCA features of tissues from HCC tissues were remarkably similar to the serum FUCA characteristics of HCC patients [22].

Our study aimed to purify and characterize $\alpha$-L-fucosidase as a medically relevant enzyme isolated from the serum of patients with HCC. Moreover, the SDS- Page Electrophoresis technique was used to study the purity of the purified $\alpha$-L fucosidase and estimate its molecular weight. The study of the cytotoxic effect of the tetrazolium cultivated (TCC), prostate (PC3), and standard hepatocyte lines were also conducted using cultured tetrazolium (MTT) (WRL-68).

\section{Material and Methods}

Population study. The study was conducted on 40 patients with hepatocellular cancer of both sexes, 22 males and 18 females, whose ages ranged from 28 to 70 years, and for the period between December 15, 2020, and March 25, 2021. Samples were taken from patients attending the oncology hospital in Mosul.

All patients diagnosed by specialists underwent a physical and clinical examination of the disease. In this study, patients with any other malignant tumors were excluded.
According to the study protocol by the Ethics Committee at the University of Mosul/College of Science and the Health Department in Nineveh, the study was conducted. All participants agreed to conduct the study

Sample collection. Five milliliters of venous blood were drawn. After coagulation for $20 \mathrm{~min}$ at $37^{\circ} \mathrm{C}$, it was centrifuged for twenty minutes at $3000 \times$ g. Serum was collected and stored at $80^{\circ} \mathrm{C}$.

\section{Assay of $\alpha-L$-fucosidase concentration/con- tent/amount and protein concentration}

The enzyme-linked immunosorbent assay (ELISA) method was used to determine $\alpha$-Lfucosidase activity. This BioAssay(TM) kit uses a sandwich ELISA to assess FUCA in human serum, plasma, and other biological fluids in vitro. The manufacturer's instructions were followed when conducting the test (Bioscience). All samples were diluted in a dilute solution at a ratio of one to fifty before being measured.

Sandwich-ELISA is used as the test method in this BioAssay(TM) ELISA kit. An antibody specific to human FUCA has been pre-coated on the micro ELISA plate included in this kit ( $\alpha$-L-Fucosidase, Tissue). Standards or samples are mixed with the specified antibody in the corresponding micro ELISA plate wells. After that, each microplate well is incubated with an Avidin-Horseradish Peroxidase (HRP) mix and a biotinylated antibody specific for human FUCA ( $\alpha$-L-fucosidase). Components that aren't needed are washed out. The substrate mixture is placed into each well. Blue will only appear in the wells containing human FUCA, biotinylated detecting antibody, and Avidin-HRP conjugate. The enzyme-substrate reaction is interrupted when Stop Solution is added, and the color turns yellow. The optical density (OD) is determined using spectrophotometry at a wavelength of $450 \mathrm{~nm} 2 \mathrm{~nm}$. The OD is proportional to how much human FUCA is present in the sample. The concentration of human FUCA can be measured by comparing the OD of the samples to the standard curve.

Bradford method was used to determine protein concentration at each step of FUCA purification, using Coomassie bright blue G-250 and cow serum albumin as standard protein [28].

\section{Purification of $\alpha$ - $L$-fucosidase}

Precipitation of FUCA. Solid ammonium sulfate was gradually added at $65 \%$ saturation to $50 \mathrm{ml}$ crude enzyme (serum) with a slow magnetic stirring procedure for $60 \mathrm{~min}$. Then the supernatant was 
discarded after chilled centrifugation at $300 \times \mathrm{g}$ for 20 min [29]. The precipitate was dissolved in an appropriate volume of a citrate solution of $\mathrm{pH}$ 5.0.

Ion Exchange Chromatography. FUCA precipitated with $65 \%$ ammonium sulfate was passed through a DEAE-Cellulose column $(2.5 \mathrm{~cm} \times 35 \mathrm{~cm})$.

A DEAE-Cellulose column was made using the modified procedure [22] by dissolving $20 \mathrm{~g}$ of resin in $1 \mathrm{~L}$ of distilled water. The beads were then allowed to settle before being cleaned with distilled water many times until they were completely clear. The suspension was filtered through Whatman No. 1 using a Buchner funnel after discharge. The resin was resuspended in a $0.25 \mathrm{M}$ sodium chloride and sodium hydroxide solution. The suspension was filtered and washed many times with $0.25 \mathrm{M}$ hydrochloric acid solution and then distilled water before being equilibrated with $0.05 \mathrm{M}$ Tris-HCl buffer pH 8.0 as previously described. The ammonium sulfate precipitates were then passed over a DEAE-Cellulose column $(2.5 \mathrm{~cm} \times 35 \mathrm{~cm})$ previously equilibrated with $0.05 \mathrm{M}$ Tris-HCl buffer $\mathrm{pH}$ 8.0. The column was then washed with an equivalent volume of the same buffer, and the bound proteins were eluted in steps with increasing sodium chloride concentrations $(0.1-1 \mathrm{M})$. The flow rate was $1 \mathrm{ml} /$ fraction throughout the column, and the absorbance of each fraction was measured at $280 \mathrm{~nm}$ with a UVVIS spectrophotometer. The $\alpha$-L-fucosidase activity in each fraction was assessed as described in the assay of $\alpha$-L-fucosidase activity and protein concentration. Fractions with $\alpha$-L-fucosidase activity were pooled and saved for subsequent purification processes [22].

Gel Filtration Chromatography. Pharmacia Fine Chemicals Company provided the instructions for making Sephadex G-200. Sephadex G-200 was dissolved in $0.01 \mathrm{M}$ Tris-HCl buffer $\mathrm{pH} 8$, degassed, and packed into a glass column $(2 \mathrm{~cm} \times 55 \mathrm{~cm})$ with the same buffer. The ion exchange stage loaded concentrated $\alpha$-L-fucosidase into the column. The elution flow rate was $2 \mathrm{ml} /$ fraction, and the equilibration buffer was the same. Each fraction's absorbance was measured at $280 \mathrm{~nm}$. The test of $\alpha$-L-fucosidase activity and protein concentration was used to assess the alpha-L-fucosidase activity in each fraction. Fractions containing $\alpha$-L-fucosidase activity were pooled and saved for further purification [30, 31].

Determine the purity and molecular weight of $\alpha$-L-fucosidase

SDS-Page electrophoresis technique was used; protein standards were used to determine the mo- lecular weight of FUCA after electrophoresis, and migratory protein distances were calculated [22, 32].

The purity of $\alpha$-L-fucosidase was determined using the SDS-Page electrophoresis technique; in reference, proteins with known molecular weights in the range of 50 to $100 \mathrm{kDa}$ and migrating protein distances were estimated.

SDS polyacrylamide gel $(8 \mathrm{~cm} \times 8 \mathrm{~cm}$, $0.75 \mathrm{~mm}$ ) in the existence of reference proteins with known molecular weights and migrating protein distances were estimated. The distances of protein migration were determined after electrophoresis to determine the enzyme molecular weight using the modified approach $[22,32]$. The presence of subunits was evaluated in $12 \%$ polyacrylamide gels $(8 \mathrm{~cm} \times 8 \mathrm{~cm}, 0.75 \mathrm{~mm})$ containing $0.1 \%$ SDS [22].

In brief, $5 \%$ stacking and $12 \%$ running gels were run at room temperature for $30-40 \mathrm{~min}$ at $80 \mathrm{~V}$ and $1-1.5 \mathrm{~h}$ at $100 \mathrm{~V}$ in $25 \mathrm{mmol} / \mathrm{l}$ Tris- $\mathrm{HCl}$, $0.2 \mathrm{~mol} / 1$ glycine buffer ( $\mathrm{pH} 8.3$ ) containing 0.1 percent SDS. FUCA samples (20-25 g/lane) were electrophoresed after $3 \mathrm{~min}$ in a boiling water bath with 2\% SDS, 5\% 2-mercaptoethanol, 25\% glycerol, and 0.1 percent bromophenol blue in $60 \mathrm{mmol} / \mathrm{l}$ Tris$\mathrm{HCl}$ (pH 6.8). Preserved molecular weight standards were used and stained under the same conditions. The gels were stained in glacial acetic acid for $3 \mathrm{~h}$ : methanol: distilled water (10:45:45, v/v/v) with 0.25 percent Coomassie brilliant blue R-250, then glacial acetic acid: methanol: distilled water (10:45:45, v/v/v) without Coomassie brilliant blue R-250 for 20 min per time[22].

\section{The cytotoxic effect of $\alpha$-L-fucosidase}

The cell lines of each hepatocellular carcinoma HepG2, prostate cancer PC3 cell line, and the standard hepatocyte cell line WRL-68 were obtained from the University of Malaya Kuala Lumpur/College of Medicine/Department of Pharmacy/Center for Natural Products Research and Drug Discovery in Malaysia for this analysis. At Baghdad's CAC. Center for Research and Biotechnology, cancer streak cells were preserved, created, and examined.

The cytotoxic effect of $\alpha$-L-fucosidase on cell lines was determined using the MTT assay. Methylthiazolyldiphenyl-tetrazolium (MTT) solution $(10 \mathrm{ml})$ was added to each well of a 96-well plate, which was then incubated for four $\mathrm{h}$ at $37^{\circ} \mathrm{C}$ with the research sample (the solution converted yellow) (the solution converted yellow). After that, each well was filled with $0.2 \mathrm{ml}$ of DMSO (dimethyl sulfoxide) and shaken for 5 min (the DMSO solution converted 
purple). Following complete dye dissolution, the absorbance of the red-stained solution was measured at $575 \mathrm{~nm}$ using an ELISA reader. The average absorbance was calculated for each group of iterations. Cell Viability \%= [Absorbance of treated sample/Absorbance of non-treated sample] $\times 100$ (Non-treated cultures contained only the medium).

Statistical analysis. The findings of this research were expressed as mean \pm SD. Using Minitab software was used to interpret the data.

\section{Results and Discussion}

$\alpha$-L-fucosidase activity (EC 3.2.1.51) was studied in several sources, due to its significance in organism and metabolism disorders [1, 4, 17-24]. The mean age of patients was $63.5 \pm 11.2$ years.

$\alpha$-L-fucosidase was purified from the serum of HCC patients under optimal conditions; the three purification steps are summarized in Table 1. The specific activity of FUCA at the precipitation stage was $0.92 \mathrm{U} / \mathrm{mg}$ protein

DEAE-cellulose chromatography purification improved enzyme activity even further. The graph below (Fig, 1) depicts the enzyme activity and specific activity for serum FUCA. According to the findings, the first peak, which occurred in a washing step with fractions numbers from 34 to 41, included enzyme-specific activity $(1.3 \mathrm{U} / \mathrm{ml})$. The specific activity of the second peak (eluted at $0.5 \mathrm{NaCl}$ ) was $5.9 \mathrm{U} / \mathrm{ml}$ at fractions numbers from 125 to 138 , with a purification fold of 11.6 and a yield recovery of $60.4 \%$.

After purification by ion exchange, the final step in the purification of FUCA from sera patients with hepatocellular cancer was the gel filtration chromatography technique, which yielded a high specific activity of $14 \mathrm{U} / \mathrm{mg}$ with a 27.5 purification fold and yield recovery of 54\% (as shown in Fig. 2). Li et., 2006 found that the specific activity of the FUCA, which isolated from hepatocellular tissue carcinoma, a closed from our result [22].

Also, Fig. 3 depicts the advanced $\alpha-L-$ fucosidase purification steps (from crude to purify enzyme) in SDS-PAGE chromatography for serum hepatocellular cancer alpha-L-fucosidase. According to the results, the purified alpha-L-fucosidase has a single band with a molecular weight of $56 \mathrm{kDa}$, similar to other studies $[22,33]$. While different from other previous studies [23, 24, 26, 27, 34, 35]. The fact source of the enzyme studied differed in some studies may explain the discrepancy in the findings.
The MTT assay was used to determine the cytotoxic effect of purified FUCA on each of heterogeneous human hepatocellular carcinoma HepG2, prostate cancer PC3 cell lines, the standard hepatocyte cell line WRL-68 for the comparison. To determine the characteristics of the cytotoxicity effect for purified FUCA on cancer cells, three cell lines were selected to be investigated; hepatocellular carcinoma HepG2, prostate cancer PC3 cell lines, and the standard hepatocyte cell line WRL-68 for the comparison. The effect of purified FUCA on cancerous cell line HepG2 and PC3 as well as the control non-cancerous WRL-68 cell line. The cytotoxicity of purified FUCA was measured as a percentage of cell viability calculated by MTT assay in each of HepG2, PC3 cells, respectively, in a dose-dependent manner after incubation with the purified enzyme for $24 \mathrm{~h}$ at $37^{\circ} \mathrm{C}$. The results (Table 2 and 3) showed that purified FUCA at different concentration (25$400 \mathrm{mg} / \mathrm{ml}$ had a cytotoxic effect on HepG2 cell line higher than that of PC3 cell line and this effect increased with the decreasing in concentration. The $\mathrm{IC}_{50}$ which is the half maximal inhibitory concentration for cell growth constructing adose-response curve was measured. Purified FUCA showed $\mathrm{IC}_{50}$ $214.5 \mu \mathrm{g} / \mathrm{ml}$ against HepG2 cell line, whereas an IC $_{50}$ of $182.1 \mu \mathrm{g} / \mathrm{ml}$ was obtained from the purified FUCA against PC3 cell line. At different concentrations of purified FUCA (25-400 $\mu \mathrm{g} / \mathrm{ml})$ and incubate it with cancer and standard cell lines at $37^{\circ} \mathrm{C}$ for $24 \mathrm{~h}$. Cell inhibitory reached to $94.65 \pm 0.85 \%$ using $25 \mu \mathrm{g} / \mathrm{ml}$ concentration of purified FUCA this finding suggest the sensitivity of HepG2 cell line to purified enzyme in a dose dependent manner which is due to cell death (Fig. 4 and 5). However, purified FUCA did not show significant toxicity on normal cell tested WRL-68 cell line (Fig. 4 and 5).

The MTT assay was used to determine the toxic effect of purified alpha-L-fucosidase from the serum of patients with hepatocellular cancer on studying the cytotoxic anticancer effect of $\alpha$-L-fucosidase against HepG2, PC3, and WRL-68 cell lines were done by using the different concentrations of purified FUCA (25-400 $\mu \mathrm{g} / \mathrm{ml})$ and incubate it with cancer and standard cell lines at $37^{\circ} \mathrm{C}$ for $24 \mathrm{~h}$. It was found that FUCA has a toxic effect on the HepG2 cell line more than PC3 when compared with normal cell line WRL-68. Purified FUCA was revealed to inhibit HepG2 cancer cell line growth with an $\mathrm{IC}_{50}$ value of $65.74 \mu \mathrm{g} / \mathrm{ml}$ compared to an $\mathrm{IC}_{50}$ of $214.5 \mu \mathrm{g} / \mathrm{ml}$ for purified FUCA against standard WRL-68 cell line. 
Ta b le 1. Purification steps for $\alpha$-L-fucosidase from hepatocellular cancer patients' serum

\begin{tabular}{|l|c|c|c|c|c|c|c|}
\hline \multicolumn{1}{|c|}{ Purification steps } & $\begin{array}{c}\text { Volume, } \\
\mathrm{ml}\end{array}$ & $\begin{array}{c}\text { FUCA } \\
\text { activity, } \\
\mathrm{U} / \mathrm{ml}\end{array}$ & $\begin{array}{c}\text { Protein } \\
\text { concentration, } \\
\mathrm{mg} / \mathrm{ml}\end{array}$ & $\begin{array}{c}\text { Specific } \\
\text { activity, } \\
\mathrm{U} / \mathrm{mg}\end{array}$ & $\begin{array}{c}\text { Total } \\
\text { activity, } \\
\mathrm{U}\end{array}$ & $\begin{array}{c}\text { Purification, } \\
\text { folds }\end{array}$ & $\begin{array}{c}\text { Yield, } \\
\%\end{array}$ \\
\hline Crude enzyme & 50 & 28 & 55 & 0.51 & 1400 & 1 & 100 \\
\hline $\begin{array}{l}\text { Ammonium sulfate } \\
\text { precipitation 65\% }\end{array}$ & 35 & 33 & 36 & 0.92 & 1155 & 1.8 & 82.5 \\
\hline $\begin{array}{l}\text { Ion exchange } \\
\text { chromatography } \\
\text { DEAE-cellulose/ } \\
\text { washing fraction } \\
\text { no. (19-23) }\end{array}$ & 8 & 25 & 19 & 1.3 & 200 & 3.4 & 14.3 \\
\hline $\begin{array}{l}\text { Ion exchange } \\
\text { chromatography } \\
\text { DEAE-cellulose/ } \\
\text { elution fraction } \\
\text { no. (60-71) }\end{array}$ & 13 & 65 & 11 & 5.9 & 845 & 11.6 & 60.4 \\
\hline $\begin{array}{l}\text { Gel filtration } \\
\text { Sehadex G-200/ } \\
\text { elution volume } \\
\text { at (40-52) ml }\end{array}$ & 12 & 63 & 4.5 & 14 & 756 & 27.5 & 54 \\
\hline
\end{tabular}

Note: $\alpha$-L-fucosidase $(\mathrm{U} / \mathrm{ml})$ activity is defined as the amount of enzyme required to remove a nanomole of fucose for a minute. The specific activity (U/mg) of the $\alpha$-L-fucosidase $(\mathrm{U} / \mathrm{mg}$ ) is defined as the amount of enzyme required to remove nanomolar fucoside per milliliter for a minute per milligram of protein.

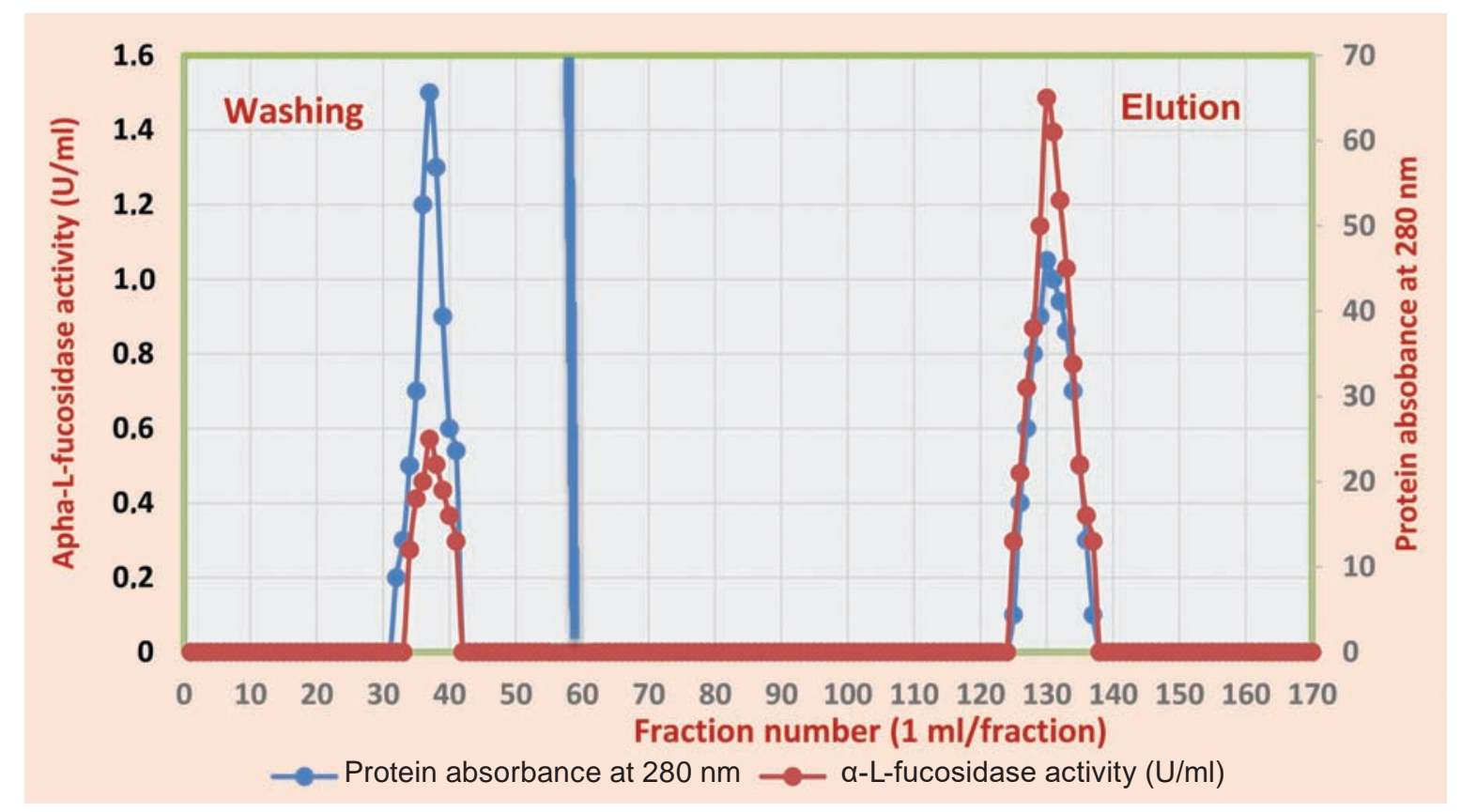

Fig. 1. Ion exchange DEAE-cellulose column $(2.5 \mathrm{~cm} \times 35 \mathrm{~cm})$ chromatography with a flow rate of $1 \mathrm{ml} / \mathrm{frac}$ tion for $\alpha$-L-fucosidase produced from the serum of patients with hepatocellular cancer (HCC) patients 


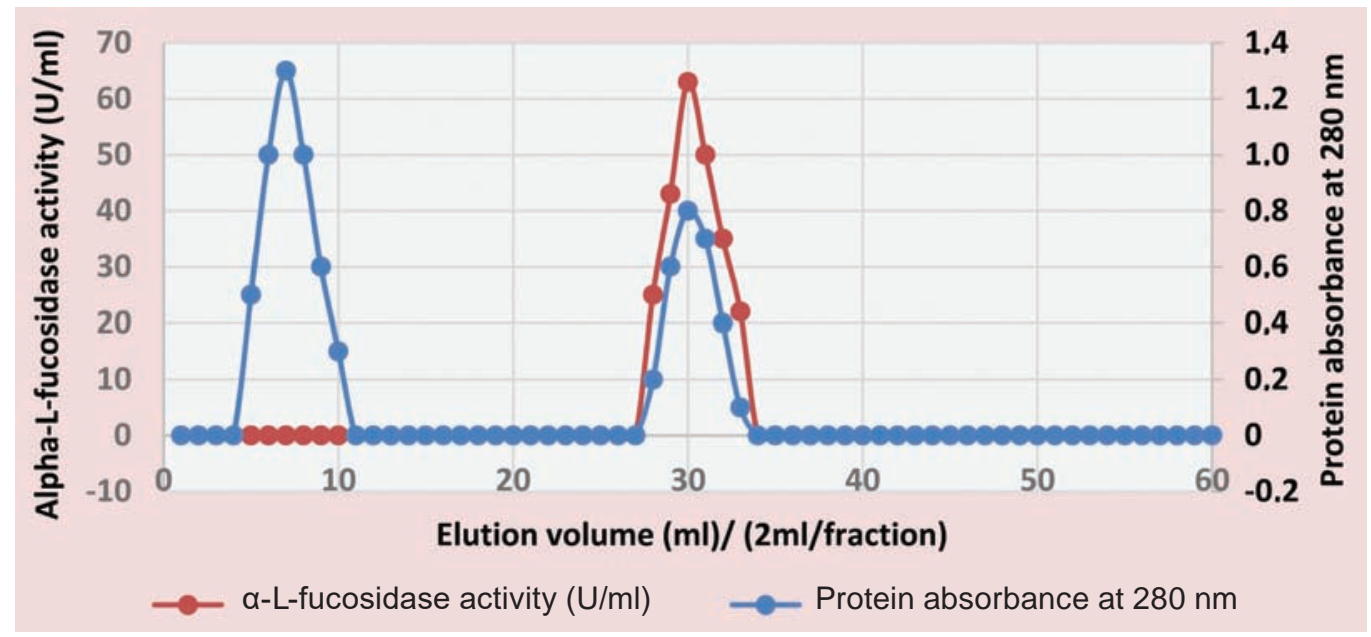

Fig. 2. Gel filtration chromatography column $(2 \mathrm{~cm} \times 55 \mathrm{~cm}) /$ Sephadex-G-75 with a flow rate of $2 \mathrm{ml} /$ fraction for $\alpha$-L-fucosidase produced from the serum of patients with hepatocellular cancer patients

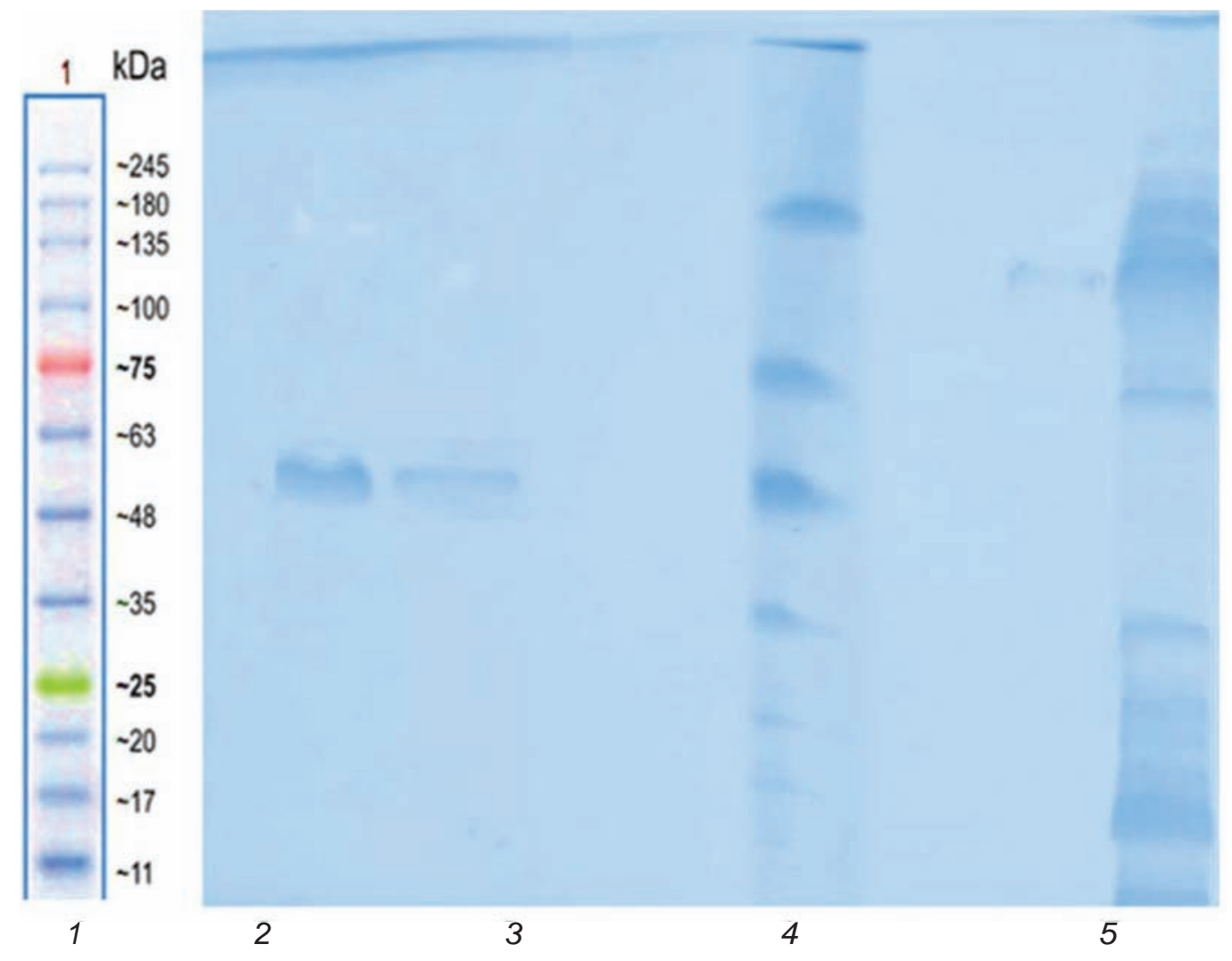

Fig. 3. SDS polyacrylamide gel electrophoresis of purified and crude $\alpha$-L-fucosidase produced by sera patients with hepatocellular cancer: 1 - proteins markers from the manufacture; 2 - protein band after gel filtration step; 3 - proteins bands after ion exchange step; 4 - proteins after precipitation of enzyme with 65\%; 5 - proteins bands in the crude filtrate

In contrast, the purified enzyme showed less inhibition growth of PC3 cancer cell line with $\mathrm{IC}_{50}$ of $111.5 \mu \mathrm{g} / \mathrm{ml}$ compared to an $\mathrm{IC}_{50}$ of $182.1 \mu \mathrm{g} / \mathrm{ml}$ for purified FUCA against standard WRL-68 cell line.
Besides, this effect increases at low concentrations of $25 \mu \mathrm{g} / \mathrm{ml}$ and decreases with increasing concentration, as shown in Tables 2 and 3. 


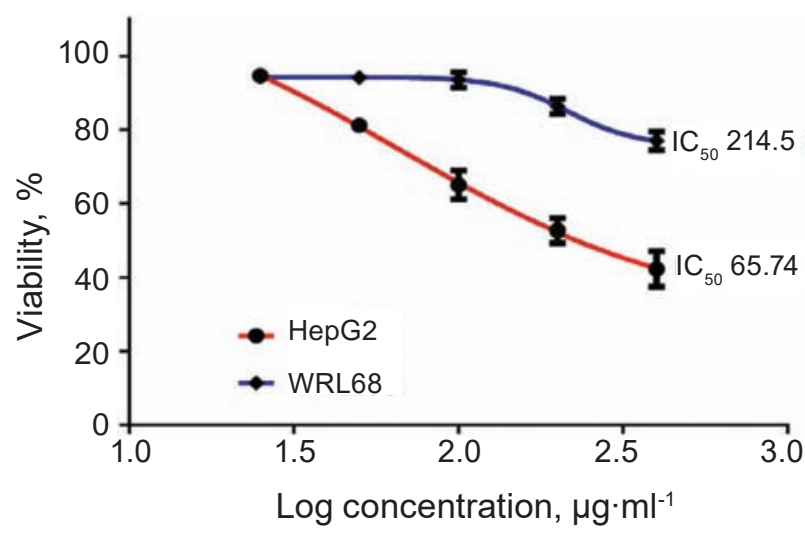

Fig. 4. Cytotoxic activity of purified $\alpha$-L-fucosidase produced from the serum of patients with hepatocellular cancer on HepG2 and WRL-68 cell lines using MTT test after $24 \mathrm{~h}$ and $37^{\circ} \mathrm{C}$

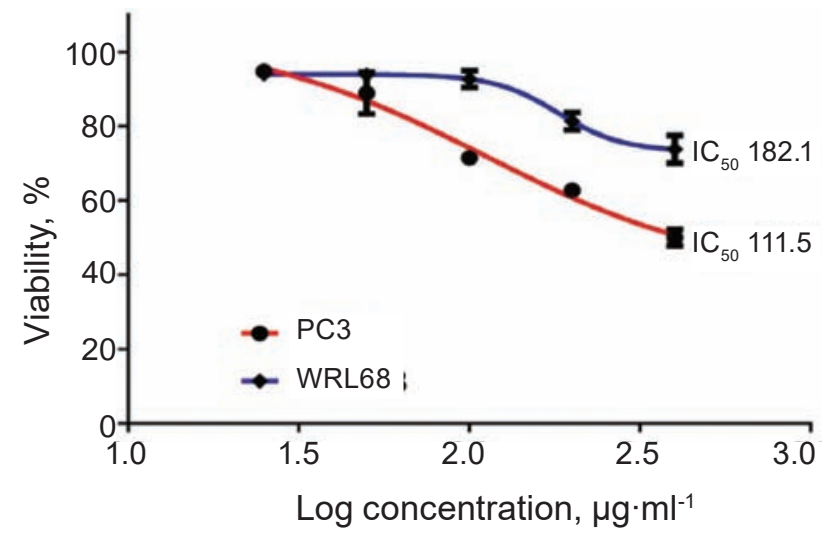

Fig. 5. Cytotoxic activity of purified $\alpha$-L-fucosidase produced from the serum of patients with hepatocellular cancer on PC3 and WRL-68 cell lines using MTT test after $24 \mathrm{~h}$ and $37^{\circ} \mathrm{C}$

Ta ble 2. Inhibition ratio for HepG2 cancer cell line and standard cell line WRL-68 in incubation for $24 \mathrm{~h}$ at $37^{\circ} \mathrm{C}$ by purified $\alpha$-L-fucosidase (FUCA) at different concentrations

\begin{tabular}{c|c|c}
\hline \multirow{2}{*}{$\begin{array}{c}\text { Concentration of } \\
\text { purified FUCA }(\mu \mathrm{g} / \mathrm{ml})\end{array}$} & $\begin{array}{c}\text { Inhibition (\%) by purified } \\
\text { FUCA on HepG2 cell line }\end{array}$ & $\begin{array}{c}\text { Inhibition (\%) by purified } \\
\text { FUCA on WRL-68 cell line }\end{array}$ \\
\cline { 2 - 3 } & Mean \pm SD & Mean \pm SD \\
\hline 400 & $42.38 \pm 4.85$ & $76.97 \pm 2.58$ \\
200 & $52.66 \pm 3.33$ & $86.34 \pm 2.09$ \\
100 & $64.97 \pm 3.85$ & $93.60 \pm 2.10$ \\
50 & $81.14 \pm 0.82$ & $94.17 \pm 0.44$ \\
25 & $94.65 \pm 0.85$ & $94.44 \pm 0.87$ \\
\hline
\end{tabular}

Ta b le 3. Inhibition ratio for prostate cancer cell line PC3 and standard cell line WRL-68 in incubation for 24 h at $37^{\circ} \mathrm{C}$ by purified $\alpha$-L-fucosidase (FUCA) at different concentrations

\begin{tabular}{c|c|c}
\hline \multirow{2}{*}{$\begin{array}{c}\text { Concentration of } \\
\text { purified FUCA }(\mu \mathrm{g} / \mathrm{ml})\end{array}$} & $\begin{array}{c}\text { Inhibition (\%) by purified } \\
\text { FUCA on PC3 cell line }\end{array}$ & $\begin{array}{c}\text { Inhibition (\%) by purified } \\
\text { FUCA on WRL-68 cell line }\end{array}$ \\
\cline { 2 - 3 } & Mean \pm SD & Mean \pm SD \\
\hline 400 & $50.00 \pm 2.20$ & $73.69 \pm 3.76$ \\
200 & $62.65 \pm 1.16$ & $81.33 \pm 2.37$ \\
100 & $71.41 \pm 1.22$ & $92.67 \pm 2.30$ \\
50 & $88.90 \pm 5.63$ & $93.75 \pm 1.42$ \\
25 & $94.75 \pm 1.08$ & $94.02 \pm 1.69$ \\
\hline
\end{tabular}

The $\alpha$-L-fucosidase properties can be isolated, purified, and examined in HCC serum as a helpful marker for early detection and a progressional disease indicator. In contrast, $\alpha$-L-fucosidase activity was previously reported as a valuable marker to de- tect disease in primary serum hepatocytes [11, 3640]. The serum FUCA characteristics of HCC patients were very close to the results of the FUCA characteristics of tissues from HCC tissues [22]. This means that it is possible to study the proper- 
ties of $\alpha$-L-fucosidase in the serum of patients with liver cancer; You can give us information about the enzyme in liver cancer tissue.

The study results showed that FUCA purified from the serum of HCC patients showed a more toxic effect on the growth of HepG2 cells than its inhibitory effect on the development of PC3 prostate cancer cells. This provides a benefit that the enzyme could be used in the study of anti-liver cancer drugs

The inhibitory effect of FUCA purified from HCC patients' blood varied depending on its concentration, presumably due to the impact of cancer cell receptors with variable concentrations of the purified FUCA enzyme, which plays an essential role in apoptosis [41]. The findings of our study revealed that the higher the concentration of the purified enzyme, the lower the rate of inhibition of cancer cells, implying an inverse relationship between concentration and rate of inhibition. This condition is known as antagonistic in the effect of dosing (Hormesis), and it is a common biological phenomenon in toxicology and pharmacology. This phenomenon is employed in the treatment of incurable diseases like Alzheimer's and cancer with low quantities of harmful substances or pollutants, as tiny concentrations of specific compounds can destroy cancer cells without damaging normal cells [42]. This could be due to the enzyme purified alpha-L-fucosidase inhibiting the release of particular components from cancer cells, such as cytokines. At low concentrations, it has a more substantial inhibitory impact. According to Hamodat study 2021, the cytoxity effect of purified adenosine deaminase-2 on breast cancer line (MCF7) increased at decreasing the concentration [43]. Also, Arshad et al. (2014) found growing the content of methanolic extract of Prosopis cineraria leaves reduced the percentage of cell inhibition of the cancer cell line MCF-7 [44]. The inhibitory effect of purified alpha-L-fucosidase was based on lower concentrations rather than high concentrations, and this depends on several factors, including the substance's concentration and molecular weight, as the higher the substance's concentration is low, the easier it is to penetrate the outer membrane in the cell wall, but not to reduce the dilution that makes it possible [44].

Conclusion. It is possible to conclude that the isolated enzyme differs in its properties according to its source. The inhibitory effect of the purified enzyme is more on hepatocellular carcinomas than on prostate cancer cells. The purified enzyme could be used in studies of the development of anticancer drugs in liver cancer. Also, the efficacy is more significant at a lower concentration. These results help in using purified alpha-L-fucosidase as an anticancer drug for the liver, which indicates that the purified enzyme can be used as an anticancer drug for the liver.

Conflict of interest. Authors have completed the Unified Conflicts of Interest form at http://ukrbiochemjournal.org/wp-content/uploads/2018/12/ coi_disclosure.pdf and declare no conflict of interest.

Acknowledgments. I extend my thanks and appreciation to the Deanship of the College of Science, especially the Dean of the College of Science, Assistant Professor Dr. Hayam Adel Al-Taie and Prof. Dr. Asaad Faisal Khattab, Head of the Department of Chemistry as well as to the Presidency of Nineveh Health; and in particular, Dr. Abdel Qader Salem, Director of the Oncology Hospital in Mosul and its employees to make available The field for conducting an investigative study.

\section{ВЛАСТИВОСТІ АЛЬФА-L- ФУКОЗИДАЗИ ІЗ СИРОВАТКИ КРОВІ ПАЦІЕНТІВ ІЗ ГЕПАТОЦЕЛЮЛЯРНОЮ КАРЦИНОМОЮ ТА ÏÏ ЦИТОТОКСИЧНИЙ ЕФЕКТ НА ДЕЯКІ ЛІНІЇ РАКОВИХ КЛІТИН}

\section{Z. M. A. A. Hamodat \\ University of Mosul, College of Science, Chemistry Department, Mosul - Iraq; e-mail: zahraahamodat@uomosul.edu.iq}

Альфа-L-фукозидаза (FUCA) це ензим, що розщеплює фукозильовані глікани і визнаний пухлинним маркером, пов'язаним iз раннім виявленням деяких видів раку. Метою цього дослідження було очистити та охарактеризувати альфа-L-фукозидазу із сироватки крові пацієнтів із гепатоцелюлярною карциномою (ГЦК) та оцінити іiі токсичний ефект щодо гепатоцелюлярної карциноми $\mathrm{HepG} 2$, клітинних ліній раку передміхурової залози PC3 та стандартної лінії гепатоцитів WRL-68. Для визначення чистоти виділеної альфа-Lфукозидази та оцінки їі молекулярної маси використовували SDS-ПААГ електрофорез. Очищення FUCA проводили в три стадії: осадження сульфатом амонію, іонообмінна хроматографія на DEAE-целюлозі, гель-фільтрація на Sephadex 
G-75. У результаті було виділено ензим із 27,5-кратним очищенням, питомою активністю 14 од/мг і виходом 54\%. Показано, що FUCA, отримана із сироватки крові пацієнтів із ГЦК, виявляла більш токсичний ефект на клітини HepG2 ( IC $_{50}$ 65,74 мкг/мл), ніж на клітини раку передміхурової залози РС3 ( $\mathrm{IC}_{50} 111,5$ мкг/мл) та менш токсичний ефект щодо клітин гепатоцитів WRL-68 (IC 50 214,5 мкг/мл). Ми можемо зробити висновок, що інгібуючий ефект очищеного FUCA на гепатоцелюлярну карциному більше, ніж його вплив на клітини раку передміхурової залози. Крім того, очищену FUCA можна використовувати в дослідженнях щодо розробки протипухлинних препаратів при раку печінки.

К л ю ч о в і с ло в а: альфа-L-фукозидаза, гепатоцелюлярна карцинома, клітинні лінії HepG2 та PC3, іоннообмінна хроматографія, гель-фільтрація.

\section{References}

1. Montaser MF, Sakr MA, Khalifa MO. Alpha-Lfucosidase as a tumour marker of hepatocellular carcinoma. Arab J Gastroenterol. 2012; 13(1): 9-13.

2. Sharafelldin H, Morsy A, Elghobary $H$, Osman E, Rady N. Association between TNF- $\alpha$, Interleukin-18 Polymorphisms and Risk of Hepatocellular Carcinoma in Egyptian patients. Asian Pac J Cancer Prev. 2021; 22(3): 887-891.

3. Wolf E, Rich NE, Marrero JA, Parikh ND, Singal AG. Use of Hepatocellular Carcinoma Surveillance in Patients With Cirrhosis: A Systematic Review and Meta-Analysis. Hepatology. 2021; 73(2): 713-725.

4. Zhang SY, Lin BD, Li BR. Evaluation of the diagnostic value of alpha-l-fucosidase, alphafetoprotein and thymidine kinase 1 with ROC and logistic regression for hepatocellular carcinoma. FEBS Open Bio. 2015; 5: 240-244.

5. Miyoshi E, Moriwaki K, Nakagawa T. Biological function of fucosylation in cancer biology. $J$ Biochem. 2008; 143(6): 725-729.

6. Baumann $H$, Nudelman $E$, Watanabe $K$, Hakomori S. Neutral fucolipids and fucogangliosides of rat hepatoma HTC and H35 cells, rat liver, and hepatocytes. Cancer Res. 1979; 39(7 Pt 1): 2637-2643.

7. Otero-Estévez O, Martínez-Fernández M, Vázquez-Iglesias L, de la Cadena MP, RodríguezBerrocal FJ, Martínez-Zorzano VS. Decreased expression of alpha-L-fucosidase gene FUCA1 in human colorectal tumors. Int J Mol Sci. 2013; 14(8): 16986-16998.

8. Shah M, Telang S, Raval G, Shah P, Patel PS. Serum fucosylation changes in oral cancer and oral precancerous conditions: alpha-Lfucosidase as a marker. Cancer. 2008; 113(2): 336-346.

9. Zhao YJ, Ju Q, Li GC. Tumor markers for hepatocellular carcinoma. Mol Clin Oncol. 2013; 1(4): 593-598.

10. Zhu J, Jiang F, Ni HB, Xiao MB, Chen BY, Ni WK, Lu CH, Ni RZ. Combined analysis of serum $\gamma$-glutamyl transferase isoenzyme II, $\alpha$-Lfucosidase and $\alpha$-fetoprotein detected using a commercial kit in the diagnosis of hepatocellular carcinoma. Exp Ther Med. 2013; 5(1): 89-94.

11. Khunsook S, Bean BS, McGowan SR, Alhadeff JA. Purification and characterization of plasma membrane-associated human sperm alpha-L-fucosidase. Biol Reprod. 2003; 68(3): 709-716.

12. Shuang Z, Mao Y, Lin G, Wang J, Huang X, Chen J, Duan F, Li S. Alpha-L-Fucosidase Serves as a Prognostic Indicator for Intrahepatic Cholangiocarcinoma and Inhibits Its Invasion Capacity. Biomed Res Int. 2018; 2018: 8182575.

13. Chen D, Xing N, Cui Z, Zhang C , Zhang Z, Li D, Yan L. The Value of Preoperative Alpha-LFucosidase Levels in Evaluation of Malignancy and Differential Diagnosis of Urothelial Neoplasms. J Oncol. 2020; 2020: 6723616.

14. Cheng TC, Tu SH, Chen LC, Chen MY, Chen WY, Lin YK, Ho CT, Lin SY, Wu CH , Ho YS. Down-regulation of $\alpha$-L-fucosidase 1 expression confers inferior survival for triplenegative breast cancer patients by modulating the glycosylation status of the tumor cell surface. Oncotarget. 2015; 6(25): 21283-21300.

15. Gan Y, Lian Q, Song X. Diagnostic value of alphaL-fucosidase for hepatocellular carcinoma: a meta-analysis. Tumour Biol. 2014; 35(5): 39533960.

16. Yu X, Zhang R, Yang T, Zhang M, Xi K, Lin Y, Wen Y, Wang G, Huang Z, Zhang X, Zhang L. Alpha-l-fucosidase: a novel serum biomarker to predict prognosis in early stage esophageal squamous cell carcinoma. J Thorac Dis. 2019; 11(9): 3980-3990.

17. Villar E, Calvo P, Cabezas JA. Comparative studies on blood serum alpha-L-fucosidases 
from several mammalian species. Comp Biochem Physiol B. 1978; 60(4): 459-461.

18. DiCioccio RA, Barlow JJ, Matta KL. Substrate specificity and other properties of alpha-Lfucosidase from human serum. $J$ Biol Chem. 1982; 257(2): 714-718.

19. Seo HC, Willems PJ, Kretz KA, Martin BM, O'Brien JS. Fucosidosis: four new mutations and a new polymorphism. Hum Mol Genet. 1993; 2(4): 423-429.

20. Dong S, Chang Y, Shen J, Xue C, Chen F. Purification, expression and characterization of a novel $\alpha$-1-fucosidase from a marine bacteria Wenyingzhuangia fucanilytica. Protein Expr Purif. 2017; 129: 9-17.

21. Liu SW, Li YK. Expression, Purification and Characterization of Human $\alpha$-1-Fucosidase. $J$ Chin Chem Soc. 2009; 56(4): 850-858.

22. Li C, Qian J, Lin JS. Purification and characterization of alpha-L-fucosidase from human primary hepatocarcinoma tissue. World J Gastroenterol. 2006; 12(23): 3770-3775.

23. Huang W, Li X. Significance of fucose expression in lung carcinoma and their brain metastases. Zhonghua Bing Li Xue Za Zhi. 2000; 29(4): 259262.

24. Khunsook S, Alhadeff JA, Bean BS. Purification and characterization of human seminal plasma alpha-L-fucosidase. Mol Hum Reprod. 2002; 8(3): 221-227.

25. Delacadena M, Fernandez J, Decarlos A, Martinezzorzano V, Gilmartin E, Rodriguezberrocal F. Low levels of alpha-L-fucosidase activity in colorectal cancer are due to decreased amounts of the enzymatic protein and are related with Dukes' stage. Int J Oncol. 1996; 9(4): 747754.

26. El-Houseini ME, EL Sherbiny $\mathrm{M}$, El-Din Awad MM, Amer MA, El Din AH, Hussein TD. Serum alpha-L-fucosidase enzyme activity as a marker for hepatocellular carcinoma: comparison with AFP using ROC analysis. $J$ Egypt Nat Cancer Inst. 2001; 13(4): 227-283.

27. Berteau O, McCort I, Goasdoué N, Tissot B, Daniel R. Characterization of a new alpha-Lfucosidase isolated from the marine mollusk Pecten maximus that catalyzes the hydrolysis of alpha-L-fucose from algal fucoidan (Ascophyllum nodosum). Glycobiology. 2002; 12(4): 273-282.

28. Bradford MM. A rapid and sensitive method for the quantitation of microgram quantities of protein utilizing the principle of protein-dye binding. Anal Biochem. 1976; 72(1-2): 248-254.

29. Barros RM, Ferreira CA, Silva SV, Malcata FX. Quantitative studies on the enzymatic hydrolysis of milk proteins brought about by cardosins precipitated by ammonium sulfate. Enzyme Microb Technoly. 2001; 29(8-9): 541-547.

30. De Jong JW , Keijzer E, Uitendaal MP, Harmsen E. Further purification of adenosine kinase from rat heart using affinity and ionexchange chromatography. Anal Biochem. 1980; 101(2): 407-412.

31. Daddona PE, Kelley WN. Human adenosine deaminase. Purification and subunit structure. $J$ Biol Chem. 1977; 252(1): 110-115.

32. Laemmli UK. Cleavage of structural proteins during the assembly of the head of bacteriophage T4. Nature. 1970; 227(5259): 680-685.

33. Johnson SW, Piesecki S, Wang RF, Damjanov I, Alhadeff JA. Analysis of purified human liver alpha-L-fucosidase by western-blotting with lectins and polyclonal and monoclonal antibodies. Biochem J. 1992; 282(Pt 3): 829-834.

34. Alhadeff JA, Khunsook S, Choowongkomon K, Baney T, Heredia V, Tweedie A, Bean B. Characterization of human semen alpha-Lfucosidases. Mol Hum Reprod. 1999; 5(9): 809815.

35. Alhadeff JA, Janowsky AJ. Purification and properties of human brain alpha-L-fucosidase. $J$ Neurochem. 1977; 28(2): 423-427.

36. Giardina MG, Matarazzo M, Varriale A, Morante R, Napoli A, Martino R. Serum alphaL-fucosidase. A useful marker in the diagnosis of hepatocellular carcinoma. Cancer. 1992; 70(5): 1044-1048.

37. Giardina MG, Matarazzo M, Morante R, Lucariello A, Varriale A, Guardasole V, De Marco G. Serum alpha-L-fucosidase activity and early detection of hepatocellular carcinoma: a prospective study of patients with cirrhosis. Cancer. 1998; 83(12): 2468-2474.

38. Deugnier Y, David V, Brissotv P, Mabo P, Delamaire D, Messner M, Bourel M, Legall JY. Serum alpha-L-fucosidase: a new marker for the diagnosis of primary hepatic carcinoma? Hepatology. 1984; 4(5): 889-892.

39. Bukofzer S, Stass PM, Kew MC, de Beer M, Groeneveld HT. Alpha-L-fucosidase as a serum marker of hepatocellular carcinoma in southern African blacks. Br J Cancer. 1989; 59(3): 417420. 
40. Leray G, Deugnier Y, Jouanolle AM, Lehry D, Bretagne JF, Campion JP, Brissot P, Le Treut A. Biochemical aspects of alpha-L-fucosidase in hepatocellular carcinoma. Hepatology. 1989; 9(2): 249-252.

41. Moteki H, Hibasami H, Yamada Y, Katsuzaki H, Imai $\mathrm{K}$, Komiya T. Specific induction of apoptosis by 1,8-cineole in two human leukemia cell lines, but not a in human stomach cancer cell line. Oncol Rep. 2002; 9(4): 757-760.
42. Calabrese EJ, Baldwin LA. Hormesis: the doseresponse revolution. Annu Rev Pharmacol Toxicol. 2003; 43: 175-197.

43. Hamodat ZMA. Study of serum adenosine deaminase-2 (ADA-2) activity in rheumatoid arthritis. Basrah J Sci. 2021; 39(1): 119-134.

44. Arshad N, Neubauer C, Hasnain S, Hess M. Peganum harmala can minimize Escherichia coli infection in poultry, but long-term feeding may induce side effects. Poult Sci. 2008; 87(2): 240-249. 